\title{
NỒNG Độ SẢN PHẨM KHUẾCH ĐẠI DNA DỊCH NUÔI PHÔI VÀ MộT Số YẾU Tố LIÊN QUAN TRONG PHÂN TíCH DI TRUYỀ TRƯớC LÀM TỔ LỆCH BộI NHIỄM SẮC THỂ
}

\author{
Hoàng Văn Ái ${ }^{1}$, Trịnh Thế Sơn ${ }^{1}$, Nguyễn Thanh Tùng ${ }^{1}$, \\ Phạm Đức Minh ${ }^{1}$, Hồ Giang Nam², Bùi Văn Nhật ${ }^{1}$, \\ Phạm Huy Hùng ${ }^{1}$, Bùi Thị Quyên ${ }^{1}$, Nguyễn Văn Thiện ${ }^{1}$, \\ Nguyễn Quang Thái ${ }^{1}$, Đặng Tiến Trường'
}

\section{TÓM TẮT}

Mục tiêu: Khảo sát nồng độ sản phẩm DNA dịch nuôi phôivà một số yếu tố liên quan trongphân tích di truyền trước làm tổ không xâm lấn phát hiện lệch bội nhiếm sắc thể. Vất liệu và phương pháp :31 phổi nang đủ điều kiện được nuôi theo quy trình nuôi đơn giọt từ ngày 3 , thể tích $15 \mu \mathrm{L}$, thoát màng vào ngày ba, thu dịch nuôi phôi vào ngày tạo phôi nang, khuếch đại toàn bộ hệ gen bằng bộ kít IonSingleseq, xác định nồng độ DNA bằng Qbit và một số yếu tố liễn quan. Kết quả: Tỷ lệ khuễch đại thành công trên mẫu dịch nuôi phôilà $28 / 31$ mẫu $(90,32 \%)$, mẫu tế bào lá nuôi là 30/31 phôi $(96,77 \%)$. Nống độ sản phẩm DNA từ mẫu dịch nuôi phôi là $15,37 \pm 8,75 \mathrm{ng} / \mu \mathrm{L}$, từ mẫu tế bào lá nuôi là $18,78 \pm 5,50 \mathrm{ng} / \mu \mathrm{L}$, không có sự khác biêtt giữa hai nhóm cả vể nồng đố DNA và tỷ lể khuếch đại thành công. Không có mối liên quan giữa hình thái phôi và kết quả khuếch đại toàn bố hệ gen. Nồng độ DNA của các mẫu dịch nuôi phôingày 6 cao hơn so với phôi ngày 5 . Kết luân: Tỷ lệ khuếch đại thành công trên mâu dịch nuôi phôi là $90,32 \%$, không có sự khác biêt về nồng đô sản phẩm DNA giữa nhóm mẫu dịch nuối phôi và tế bào lá nuôi; tuối phôi ảnh hưởng tới nồng độ sản phẩm khuếch đại toàn bộ hệ gen của mẫu dịch nuôi phôi.

Tư khóa: Sàng lọc lệch bội trước làm tổ không xâm lấn (niPGTA), dịch nuôi phối (SCM).

\section{SUMMARY \\ CONCENTRATION OF DNA AMPLIFICATION \\ PRODUCT IN SPENT EMBRYO CULTURE MEDIA FOR NON-INVASIVE \\ PREIMPLANTATION GENETIC TESTING}

Objective: To evaluate the DNA concentration in spent culture media after whole genome amplification and some related factors in the noninvasive preimplantation genetic test for aneuploidy. Materials and Methods: cross-sectional study of 31 blastocysts cultured in a single drop culture from day 3, volume $15 \mu \mathrm{L}$, assisted hatched on day three, collected culture sample on the day of full blastocyst formation, amplified the whole genome with the IonSingleseq kit

${ }^{1}$ Học viện Quân Y

²Bệnh viện Sản Nhi Nghệ An

Chịu trách nhiệm chính: Đặng Tiến Trường

Email: truongdr@vmmu.edu.vn

Ngày nhận bài: 12/4/2021

Ngày phản bnieenj khoa học: 29/4/2021

Ngày duyệt bài: 20/5/2021 kit DNA concentration evaluation using Qbit hsDNA. Results: in our study, the amplification rate of culture media sample was $28 / 31$ samples (90.32\%), trophectoderm biopsy sample was 30/31 embryos $(96.77 \%)$. The concentration of the DNA product in the post-amplified in culture media sample was 15.37 $\pm 8.75 \mathrm{ng} / \mu \mathrm{L}$. The DNA concentration of the trophectoderm biopsy sample was $18.78 \pm 5.50 \mathrm{ng} / \mu \mathrm{L}$, the difference between the invasive and non-invasive groups was not statistically significant. There is no statistically relationship between embryo morphology and genome amplification results. DNA concentration of SCM samples of day 6 embryo was higher than day 5 embryo.Conclusion: The successful amplification rateof SCM samples is $90.32 \%$, there is no statistically difference in concentration of DNA products between SCM and TE samples; The blastocyst day affects the DNA concentration of the whole genome amplification product in the SCM sample.

Keywords; niPGT-A, SCM, embryo culture, noninvasive, pre-implantation genetic test, NGS

\section{I. ĐĂT VẤN ĐỀ}

Hiện nay, phân tích di truyên trước làm tổ không xâm lấn (niPGTA) là xu hướng mới trong lĩnh vực hỗ trợ sinh sản, một kỹ thuật giúp tránh chuyển phôi bất thường vào buồng tử cung người mẹ mà không cân phải sinh thiết phôi. Phương pháp này được tập trung nghiên cứu vì phương pháp thu thập mẫu xâm lấn như sinh thiết thể cực, sinh thiết tế bào phôi ở các giai đoan khác nhau gây ảnh hưởng đến sự phát triển phôi, và kết quả thụ tinh trong ống nghiệm [1]. Việc thu thập các mẫu DNA từ mẫu dịch nuôi phôi (SCM), dịch phôi nang (BF) hoặc kết hợp thu dịch phôi nang và dịch nuôi phôi (BF + SCM) phục vụ phân tích di truyền trước làm tổ lệch bội nhiệm sắc thể, không cân phải sinh thiết phôi, thể cực được tập trung nghiên cứu và đánh giá. Tuy nhiên, phương pháp thu mẫu DNA từ dich nuôi phôi vấn được coi là an toàn nhất vì đây là phương pháp không xâm lấn hoàn toàn. Việc sử dụng mẫu SCM cân được đánh giá đây đủ hiệu quá khuếch đại DNA, các yếu tố ảnh hưởng của phôi liên quan đến nồng độ DNA thu được. Vì vậy, nghiên cứu bước đâu này được tiến hành với mục tiêu: Khảo sát nồng đô sản phẩm DNA dịch nuôi phôi và một số yếu tố liên 
quan trong phân tích di truyền trước làm tổ lệch bội nhiễm sắc thế.

\section{II. ĐỐI TƯợNG VÀ PHƯƠNG PHÁP NGHIÊN CỨU}

2.1. Đối tượng nghiên cứu. 31 phôi nang đủ điều kiện được nuôi theo quy trình nuôi đơn giọt từ ngày 3 được tuyển chọn theo phương pháp lấy mẫu thuận tiện, gồm phôi từ các cặp vợ chồng có chỉ định PGT-A tình nguyện tham gia nghiên cứu từ tháng 3/2020 tới tháng 11/2020 tại Viện Mô phôi lâm sàng Quân đội.

2.2. Phương pháp nghiên cứu. Phương pháp nghiên cứu quan sát mô tả cắt ngang.

Quy trình xử lý noãn và nuôi phôi đơn giọt bao được tóm tắt như sau: Tìm phức hợp noãn-nang, ủ noãn, loại bỏ tế bào nang bằng enzyme hyaluronidase; tiêm tinh trùng vào bào tương noãn, theo dõi thụ tinh; đánh sự phát triển, và hình thái phôi phân cắt tai ngày 3 , rửa phôi, chuyển các phôi sang môi trường nuôi đơn giọt $(15 \mu \mathrm{L})$, hỗ trợ thoát màng bằng laser; đánh giá sự phát triển phôi nang và hình thái phôi (blastocyst) tại N5 hoăc N6; thu thập dịch nuôi phôi và sinh thiết tế bào lá nuôi (TE).

- Khuếch đại DNA từ các mâu SCM và TE: Các mẫu SCM và TE được khuếch đại bằng bộ kit Ion Singleseq (Thermo Scienctific) theo hướng dẫn của nhà sản xuất; nồng độ DNA của sản phẩm được đo bằng bộ kít Qubit ${ }^{\top \mathrm{M}} \mathrm{dsDNA}$ HS Assay Kit (Thermo Fisher Scientific), tại phòng thí nghiệm phân tích di truyền trước làm tổ tại Phòng Phân tích DNA, Bộ môn Giải phẫu, Học viên Quân y.

- Phân tích dữ liệu: dữ liệu được phân tích bằng các thuật toán thống kê phù hợp trên phần mềm STATA.

\section{KẾT QUẢ NGHIÊN CỨU}

3.1. Kết quả khuếch đại hệ gen từ mẫu nghiên cứu

Bảng 3.1. Tỷ lệ khuếch đại toàn hệ gen thành công của mẫu SCM và TE

\begin{tabular}{|c|c|c|}
\hline Phôi nang & $\begin{array}{c}\text { Số lượng } \\
\text { khuếch đại } \\
\text { thành công (n) }\end{array}$ & $\begin{array}{c}\text { Tỷ lệ } \\
\text { (\%) }\end{array}$ \\
\hline $\begin{array}{c}\text { Mâu xét nghiệm } \\
\text { TE (n=31) }\end{array}$ & 30 & $96,77 \%$ \\
\hline $\begin{array}{c}\text { Mâu dịch nuôi } \\
\text { phôi ( } n=31)\end{array}$ & 28 & $90,32 \%$ \\
\hline
\end{tabular}

Kết quả bảng 3.1 cho thấy, tỷ lệ khuếch đại thành công ở mẩu tế bào lá nuôi là là $96,77 \%$, ở mẫu dịch nuôi phôi của phôi nang là $90,32 \%$.

Bảng 3.2. Nồng độ sản phẩm DNA của mẫu SCM và TE

\begin{tabular}{|c|c|c|c|c|}
\hline $\begin{array}{c}\text { Nồng độ sản } \\
\text { phẩm DNA }\end{array}$ & $\begin{array}{c}\text { Trung } \\
\text { bình }\end{array}$ & Min & Max & p \\
\cline { 1 - 4 } $\begin{array}{c}\text { Mấu dịch nuôi } \\
\text { phôi (ng/ul) }\end{array}$ & $\begin{array}{c}15,37 \\
\pm 8,75\end{array}$ & 1,96 & 35,8 & \multirow{2}{*}{0,07} \\
\cline { 1 - 4 } $\begin{array}{c}\text { Mâu tế bào lá } \\
\text { nuôi (ng/ul) }\end{array}$ & $\begin{array}{c}18,78 \\
\pm 5,50\end{array}$ & 2,43 & 31,7 & \\
\hline
\end{tabular}

Kết quả bảng 3.2 cho thấy không có sự khác biệt về nồng độ sản phẩm DNA giữa mẫu TE (ng/ul) và mầu SCM.

3.2. Mối liên quan giữa hình thái phôi nang, tuổi phôi và kết quả khuếch đại DNA dịch nuôi phôi phôi

Bảng 3.3. Mối liên quan giữa hình thái phôi và nồng độ sản phẩm DNA trong dịch nuôi phôi phôi

\begin{tabular}{|c|c|c|c|}
\hline Hình thái phôi & $\mathbf{n}$ & $\begin{array}{c}\text { Nồng độ sản } \\
\text { phẩm (ng/ } \mathbf{H L})\end{array}$ & $\mathbf{p}$ \\
\hline Phôi tốt & 16 & $14,28 \pm 8,51$ & \\
\cline { 1 - 3 } Phôi Trung bình & 9 & $16,87 \pm 9,52$ & \multirow{2}{*}{0,77} \\
\hline Phôi kém & 5 & $16,03 \pm 9,42$ & \\
\hline Tống & $\mathbf{3 1}$ & $\mathbf{1 5 , 3 7} \pm \mathbf{8 , 7 5}$ & \\
\hline
\end{tabular}

Kết quả bảng 3.3 cho thấy cho thấy phôi nang chất lượng trung bình có nồng độ sản phẩm DNA trong mẫu dịch nuôi phôi cao nhất $(16,87 \pm 9,52 \mathrm{ng} / \mathrm{\mu L})$, phôi nang chất lượng tốt có nồng độ thấp nhất $(14,28 \pm 8,51 \mathrm{ng} / \mu \mathrm{L})$. Tuy nhiên sự khác biệt giữa các nhóm không có ý nghĩa thống kê với $p=0,77$.

Bảng 3.4. Mối liên quan giữa hinh thái phôi và tỷ lệ khuếch đại thành công

\begin{tabular}{|c|c|c|c|c|}
\hline $\begin{array}{c}\text { Hình thái } \\
\text { phôi }\end{array}$ & $\mathbf{n}$ & $\begin{array}{c}\text { Khuếch đại } \\
\text { thành công }\end{array}$ & Tỷ lệ & p \\
\hline Phôi tốt & 16 & 14 & $87,5 \%$ & \\
\cline { 1 - 3 } $\begin{array}{c}\text { Phôi Trung } \\
\text { bình }\end{array}$ & 9 & 9 & $100 \%$ & 0,5 \\
\cline { 1 - 3 } Phôi kém & 5 & 5 & $83,33 \%$ & \\
\hline Tống & 31 & 28 & $\mathbf{9 0 , 3 2 \%}$ & \\
\hline
\end{tabular}

Kết quả bảng 3.4 cho thấy phôi nang chất lượng trung bình có tỷ lệ khuếch đại cao nhất $(100 \%)$, phôi nang chất lượng kém có tỷ lệ khuếch đại thấp nhất $(83,33 \%)$, tuy nhiên sự khác biệt giữa các nhóm không có ý nghĩa thống kê với $p=0,568$.

Bảng 3.5. Môi liên quan giữa tuổi phôi và nồng độ DNA trong mẫu dịch nuôi phôi

\begin{tabular}{|c|c|c|c|}
\hline Tuổi phôi & $\mathbf{n}$ & $\begin{array}{c}\text { Nồng độ DNA } \\
\text { (ng/ju) }\end{array}$ & p \\
\hline $\begin{array}{c}\text { Phôi nang } \\
\text { ngày 5 }\end{array}$ & 15 & $9,78 \pm 5,14$ & \multirow{2}{*}{0,001} \\
\cline { 1 - 3 } $\begin{array}{c}\text { Phôi nang } \\
\text { ngày 6 }\end{array}$ & 16 & $20,61 \pm 8,23$ & \\
\hline Tống & $\mathbf{3 1}$ & $\mathbf{1 5 , 3 7 \pm \mathbf { 8 } , \mathbf { 7 5 }}$ & \\
\hline
\end{tabular}

Kết quả bảng 3.5cho thấy nồng độ sản phấm DNA của mẫu dịch nuôi phôi ở phôi ngày $6 \mathrm{cao}$ hơn phôi ngày 5, sự khác biệt có ý nghĩa thống kê với $p=0,001$. 
Bảng 3.6. Mối liên quan giữa tuổi phôi và kêt quả khuếch đại thành công của mẫu dịch nuôi phôi

\begin{tabular}{|c|c|c|c|}
\hline Tuổi phôi & $\mathbf{n}$ & $\begin{array}{c}\text { Khuếch đại } \\
\text { thành công }\end{array}$ & Tỷ lệ \\
\hline $\begin{array}{c}\text { Phôi nang } \\
\text { ngày 5 }\end{array}$ & 15 & 12 & $80 \%$ \\
\hline $\begin{array}{c}\text { Phôi nang } \\
\text { ngày 6 }\end{array}$ & 16 & 16 & $100 \%$ \\
\hline Tổng & $\mathbf{3 1}$ & $\mathbf{2 8}$ & $\mathbf{9 0 , 3 2 \%}$ \\
\hline
\end{tabular}

Kết quả bảng 3.6 cho thấy phôi nang ngày 6 có tỷ lệ khuếch đại cao hơn ngày 5.

\section{BÀN LUẬN}

Tiềm năng của dịch nuôi phôi cung cấp nguồn DNA để phân tích PGT-A tạo ra sự quan tâm lớn đến các phòng thí nghiệm di truyển sinh sản trên thế giới. Tuy nhiên, tỷ lệ khuếch đại khác nhau đáng kể giữa các nghiên cứu.

Yeung tiến hành nghiên cứu trên 168 phôi nuôi từ ngày 3 đến ngày 5 hoặc 6 , thể tích giọt nuôi là $30 \mu \mathrm{L}$, sử dụng bộ kit WGA là sureplex, có tỷ lệ khuếch đjai thành công là $89 \%$ [2]. Tác giả Ho tiến hành nghiên cứu thu dịch nuôi phôi từ ngày 1 lên ngày 3 cho tỷ lệ khuếch đại là 39\%[3]. Gần đây, Camen Rubio tiến hành nghiên cứu thu thập dịch nuôi phôi từ ngày 4 lên ngày 6 thể tích giọt nuôi là $10 \mu \mathrm{L}$ cho tỷ lệ khuếch đại thành công là $97.4 \%[4]$. Có thể thây, việc khuếch đại thành công DNA trong xét nghiệm không xâm lấn phụ thuộc vào thời gian thu thập mẫu, việc thu thập mẩu ở những giai đoạn có sự phân cắt nhiều (N4-N6) có thể thu thập được mẫu DNA có nồng độ cao hơn so với thu thập dịch nuôi phôi ở những giai đoạn phân cắt ít hơn (N1-N3). Việc lựa chon thời điểm thu thập dịch nuôi phôi, tránh sự thoái hóa DNA trong mẫu dịch cũng vô cùng quan trọng. Thể tích giọt nuối càng lớn, cho tỳ lệ khuếch đại thường là kém hơn so với thể tích giọt nuôi bé hơn. Các nghiên cứu với thể tích giọt nuôi trên $30 \mu \mathrm{L}$ thông thường cho kết quả khuếch đại gen thấp hơn so với các nghiên cứu với thể tích giọt nuôi dưới $15 \mu \mathrm{L}$. Ngoài ra Kit xét nghiệm, phương pháp khuếch đại cũng ảnh hưởng đến tỷ lệ khuếch đại thành công. Nghiên cứu của Liu 2017 phân tích dịch nuôi phôi từngày 1-5 SCM thu được sau quá trình nuôi 88 phôi từ bảy cặp vợ chồng. Sử dụng kit MALBAC (Yikon Genomics), WGA đạt được 90,9\% mẫu, tỷ lệ giống với tỷ lế đạt được khi sử dụng sinh thiết tế bào lá nuôi. Tuy nhiên, trong nghiên cứu này, tỷ lệ khuếch đại $90 \%$ cho các mẫu TE thấp hơn đáng kể so các nghiên cứu khác [5]. Nghiên cứu của chúng tôi sử dung bộ kit Reproseq $\circledR$ của hãng ThermoFisher, Mỹ. Cho tỷ lệ khuếch đại DNA với tỷ lệ cao của cả mẫu TE và mẫu dịch nuôi phôi.

Nghiên cứu của Liu 2017 (88 mẫu) cho thây nông độ DNA trung bình thu được là 26.15

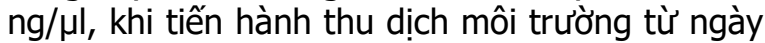
1 tới ngày 5/6 [5]. Shamonki nghiên cứu trên 57 mẫu, thu dịch môi trường từ ngày 3 tới ngày $5 / 6$; $\mathrm{AH}$ vào ngày 3 ; thể tích giọt nuôi $15 \mu \mathrm{L}$, nồng độ DNA trung bình thu được là $66 \mathrm{ng} / \mu \mathrm{l}$ [6]. Nghiên cứu của Vera 2018 thu dịch môi trường từ ngày 3 tới ngày $5 / 6$; thoát màng vào ngày 3 ; thể tích giọt nuôi $25 \mu \mathrm{L}$, tác giả có khuếch đại gen WGA 2 lần Nồng độ DNA trước

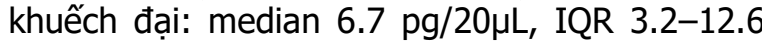
pg. Nồng độ DNA sau khuếch đại: median 4.9 $\mu g$, IQR 3.4-6.2 $\mu \mathrm{g}$ [7]. Nghiên cứu của chúng tôi thu được nồng độ sản phẩn DNA sau khuếch đại là $15.37 \pm 8.75 \mathrm{ng} / \mu \mathrm{l}$. Nghiên cứu của chúng tôi cho thấy rằng, ở những phôi chất lượng trung bình, tỷ lệ khuếch đại và nồng độ DNA là cao nhất $16.87 \pm 9.52 \mathrm{ng} / \mu \mathrm{L}$, tỷ lệ khuếch đại $100 \%$. Đối với phôi chất lượng xấu, có nồng độ DNA trung bình là $16.03 \pm 9.42 \mathrm{ng} / \mu \mathrm{L}$ với tỷ lệ khuếch đại thành công là $83.33 \%$. Về mặt phân loại, những phôi chất lượng xấu có rất ít tế bào lá nuôi liên kết lỏng lẻo và có ít tế bào nụ phôi, do đó việc thoái giáng trên số lượng ít tế bào cho kết quả nồng độ DNA thấp hơn và tỷ lệ khuếch đại thấp hơn. Nghiên cứu của chúng tôi cho thãy nồng độ cfDNA của phôi ngày 6 cao hơn có ý nghĩa thống kê với phôi ngày 5 . Quá trình thoái giáng DNA của phôi ngày 6 có thể cao hơn so với phôi ngày 5 , hoặc việc thu thập dịch nuôi phôi trong 3 ngày làm nồng độ cfDNA cao hơn.

\section{KẾT LUẬN}

Tỷ lệ khuếch đại thành công trên mẫu dịch nuôi phôi là $90,32 \%$, không có sự khác biệt về nồng độ sản phẩm DNA giữa nhóm mẫu SCM và TE; tuối phôi ảnh hưởng tới nồng độ sản phẩm khuếch đại toàn bộ hệ gen của mầu SCM.

\section{TÀI LIÊU THAM KHẢO}

1. Scott R.T., Upham K.M., Forman E.J., et al. (2013). "Cleavage-stage biopsy significantly impairs human embryonic implantation potential while blastocyst biopsy does not: a randomized and paired clinical trial." Fertil Steril, 100(3), 624-630.

2. Yeung Q.S.Y., Zhang Y.X., Chung J.P.W., et al. (2019). "A prospective study of non-invasive preimplantation genetic testing for aneuploidies (NiPGT-A) using next-generation sequencing (NGS) on spent culture media (SCM)." J Assist Reprod Genet, 36(8), 1609-1621.

3. Ho J.R., Arrach N., Rhodes-Long $K_{.}$, et al. (2018). "Pushing the limits of detection: investigation of cell-free DNA for aneuploidy screening in embryos." Fertil Steril, 110(3), 467-475.e2. 
4. Rubio C. Navarro-Sánchez L., GarcíaPascual C.M., et al. (2020). "Multicenter prospective study of concordance between embryonic cell-free DNA and trophectoderm biopsies from 1301 human blastocysts." Am J Obstet Gynecol.

5. Liu W., Liu J., Du H., et al. (2017). "Noninvasive pre-implantation aneuploidy screening and diagnosis of beta thalassemia IVSII654 mutation using spent embryo culture medium." Ann Med, 49(4), 319-328.
6. Shamonki M.I., Jin H., Haimowitz Z., et al. (2016). "Proof of concept: preimplantation genetic screening without embryo biopsy through analysis of cell-free DNA in spent embryo culture media." Fertility and Sterility, 106(6), 1312-1318.

7. Vera-Rodriguez M., Diez-Juan A., JimenezAlmazan j., et al. (2018). "Origin and composition of cell-free DNA in spent medium from human embryo culture during preimplantation development." Hum Reprod, 33(4), 745-756.

\section{KHẢO SÁT NỒNG Độ ACID URIC HUYẾT TƯƠNG Ở BÊNH NHÂN ĐÁI THÁO ĐƯờNG TÍP 2 CÓ BỆNH THẬN MẠN}

Đào Bùi Quý Quyền ${ }^{1}$, Bùi Hữu Hoàng ${ }^{2}$, Lê Việt Thắng ${ }^{3}$

\section{TÓM TẮT}

Mục tiêu: Xác định nồng độ acid uric huyết tương ở bênh nhân đái tháo đường típ 2 có bênh thân man. Đối tượng và phương pháp: Nghiên cứu cắt ngang trên 156 đối tương bao gồm 98 bênh nhân ĐTĐ típ 2 có BTMT và 58 bệnh nhân không có BTMT. Tất cả các bênh nhân được định lượng nồng đôacid uric huyết tươngtheo phương pháp enzyme. Kết quả: Nồng độ hs-CRP huyết tương trung bình ở nhóm ĐTĐ có BTMT

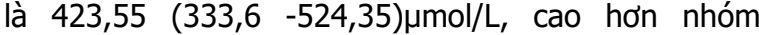

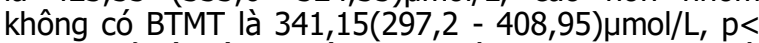
0,001 . Tỷ lệ bệnh nhân ĐTĐ có BTMT tăng AU là $60,2 \%$ cao hớn nhóm không có BTMT là $29,3 \%$, $p<$ 0,001 . Nhóm bệnh nhân ĐTĐ có BTMT tuổi từ 60 trở lên; bệnh thận mạn giai đoạn 3-5; có biến chứng khác ngoài thân có nồng đô $A U$ cao hơn nhóm không có đặc điểm trên, $p<0,05$. Kết luận: Tăng $A U$ là thường gặp ở bênh nhân ĐTĐ típ 2 có bênh thân mạn.

Tư khóa: Đái tháo đường típ 2, bệnh thận mạn tính, acid uric

\section{SUMMARY}

SURVEY ON CONCENTRATION OF PLASMA ACID URIC IN TYPE 2 DIABETIC MELLITUS PATIENTS WITH CHRONIC NEPHROPATHY

Objectives:To determine of plasma acid uric (AU)levels in type 2 diabetic mellitus (DM) with chronic nephropathy (CN). Subjects and methods: Cross-sectional study on 156 subjects including 98 patients diagnosed type $2 \mathrm{DM}$ with $\mathrm{CN}$ and 58 patients without CN. Plasma AU levels were quantified by enzyme in all the patients. Results: The median plasma $\mathrm{AU}$ concentration in the $\mathrm{DM}$ group with $\mathrm{CN}$ was 423.55 (333.6-524.35) $\mu \mathrm{mol} / \mathrm{L}$, higher than the

\footnotetext{
${ }^{1}$ Bệnh viện Chơ rẫy,

²Bênh viện Nhân dân 115

${ }^{3}$ Họ viến Quân y

Chịu trách nhiệm chính: Lê Việt Thắng

Email: lethangviet@yahoo.com.uk

Ngày nhận bài: 12/4/2021

Ngày phản biên khoa hoc: 10/5/2021

Ngày duyệt bài: 23/5/2021
}

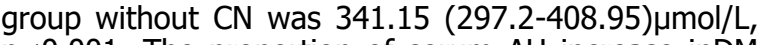
$\mathrm{p}<0.001$. The proportion of serum AU increase inDM patients with $\mathrm{CN}$ was $60.2 \%$ higher than that of the DM group without CN of $29.3 \%, p<0.001$. The AU concentration in group of DM patients with $\mathrm{CN}$ and $\geq$ 60 years old; $\mathrm{CN}$ stage 3-5; with complications others, was higher than of the one without the above characteristics, $p<0.05$. Conclusion: Increased $A U$ is common in patients with type 2 diabetic mellitus with chronic nephropathy.

Keywords: Type 2 diabetic mellitus, chronic nephropathy, acid uric.

\section{I. ĐĂT VẤN ĐỀ}

Đái tháo đường típ 2 ngày càng gia tăng trên thế giới và trẻ hoá, với cơ chế bệnh sinh liên quan đến kháng insulin và giảm chức năng tế bào beta [1],[2]. Ở bệnh nhân đái tháo đường típ 2 cần kiểm soát nhiều yếu tố gồm glucose máu, rối loạn lipid máu, huyết áp... Những bênh nhân kiểm soát kém các yếu tố, thường xuất hiện các biến chứng sớm, trong đó có biến chứng thân. Biểu hiện tổn thương thân ở bênh nhân đái tháo đường típ 2 sớm nhất là sự xuất hiện albumin niệu, cụ thể là microalbumin niệu. Trên lâm sàng biến chứng thận có thể gặp dạng protein niêu có hoặc không hội chứng thận hư, và hoặc kèm theo suy thâan man tính [3]. Acid uric máu ngày càng được nghiên cứu nhiều và được xem như một yếu tố tiên lượng độc lập nguy cơ tim mach cũng như tỷ lệ sống còn ở các bệnh nhân mắc bênh mạn tính. Nhiều nghiên cứu trên thế giới đã khẳng định: tăng nồng độ acid uric huyết thanh ở bệnh nhân đái tháo đường nói chung, bệnh nhân đái tháo đường có tổn thương thân nói riêng chính là một yếu tố nguy cơ độc lập quan trọng và có giá trị trong chẩn đoán, tiển lượng bệnh nhân [4],[5],[6]. Xuất phát từ những lý do trên, chúng tôi thực hiện đề tài này với mục tiêu: Khảo sát nồng độ 